\title{
SETD1B wt Allele
}

National Cancer Institute

\section{Source}

National Cancer Institute. SETD1B wt Allele. NCI Thesaurus. Code C142222.

Human SET D1B wild-type allele is located in the vicinity of 12q24.31 and is approximately $29 \mathrm{~kb}$ in length. This allele, which encodes histone-lysine N-methyltransferase SETD1B protein, plays a role in methylation of histone $\mathrm{H} 3$. 